\title{
Soil-Plant Factors in Early Browning of Russian Wildrye on Natrustoll Soils
}

\author{
R.A. BOWMAN, D.M. MUELLER, AND W.J. MCGINNIES
}

\begin{abstract}
The occurrence of early browning in selected areas of a 1979established Russian wildrye (Elymus junceus Fisch.) plot led to a comparison of soil-plant-water relationships in the brown senescing areas, and in adjacent green healthy areas. Although the green areas exhibited better nutrient status and less salinity-sodicity associated problems than the brown areas, the main problem and cause for this premature browning appeared to be water related.

A main objective of the rehabilitation program of the saltgrass meadows soils at the Central Plains Experimental Range (CPER) is to replace the largely unpalatable inland saltgrass [Distichlis stricta (Torr.) Rydb.] with better forage grasses and legumes for livestock consumption. These improved forages must be tolerant to drought stress and at the same time tolerant to saline-sodic soil conditions (McGinnies et al. 1976). Russian wildrye (Elymus junceus Fisch.) is one such species which is presently being used at the CPER to replace inland saltgrass.

For 2 consecutive seasons $(1980,1981)$ early browning has been noted in certain areas of a 1979-established Russian wildrye plot $(40 \mathrm{~m} \times 6 \mathrm{~m})$. These brown areas varied from entire sub-plots $(5 \mathrm{~m}$ $\times 6 \mathrm{~m})$ to parts of a sub-plot $(1 \mathrm{~m} \times 0.5 \mathrm{~m})$. In 1981 , we sampled 2 contrasting areas to assess soil and plant characteristics of both areas.
\end{abstract}

\section{Methods and Materials}

\section{Study Area}

Site description data have been reported by McGinnies et al. (1976). The area is dominated by an Avar sandy loam which is classified as fine, montmorillonitic, mesic, typic Natrustoll. Mean annual precipitation is about $310 \mathrm{~mm}$, most of which occurs between May and September. Frost-free period averages about 133 days per year with an average daily minimum of $9^{\circ} \mathrm{C}$ and an average daily maximum of $26^{\circ} \mathrm{C}$. The study area was conventionally tilled (plowed and disked) and seeded with Vinall Russian wildrye in the spring of 1979.

\section{Soil-Plant Methodology}

Soil samples were taken in July 1981 from areas that exhibited green and brown Russian wildrye plants in close proximity (about $3 \mathrm{~m}$ apart). These areas were similar in topography and slope. Four matched pair samples were taken: 2 from a large brown area $(6 \mathrm{~m} X$ $5 \mathrm{~m}$ ) and 2 from small brown areas $\left(0.5-1.0 \mathrm{~m}^{2}\right)$. Green areas were sampled as closely as possible to the matched brown areas without

\footnotetext{
Authors are soil scientist and range scientists, respectively, USDA-ARS Crops Research Laboratory, Colorado State University, Fort Collins 80523.

This article is a contribution from the USDA-ARS in cooperation with the Colorado State University Experiment Station Scientific Series No. 2802.

Manuscript received February 14, 1983.
}

sampling transitional areas. A soil coring device was used to obtain entire plants and soil cores $80 \mathrm{~cm}$ long and $15 \mathrm{~cm}$ in diameter from both areas. Soil cores were subdivided into $10-\mathrm{cm}$ increments and taken to the laboratory for plant and soil analyses. Plant samples were dried at $70^{\circ} \mathrm{C}$ for 1 day, and plant dry matter production was determined. Root weights were determined for dry matter production at $10-\mathrm{cm}$ increments. All plant materials were ground and wet digested in sulfuric acid $\left(\mathrm{H}_{2} \mathrm{SO}_{4}\right)$ for nitrogen $(\mathrm{N})$, phosphorus $(\mathrm{P})$ (Technicon Autoanalyzer), potassium (K), calcium (Ca), magnesium $(\mathrm{Mg})$, sodium $(\mathrm{Na})$, iron $(\mathrm{Fe})$, zinc $(\mathrm{Zn})$, copper $(\mathrm{Cu})$, and manganese (Mn) (Atomic adsorption spectrophotometry). Boron (B) was determined on plant tops only (Soltanpour and Workman 1981).

Gravimetric soil moisture was determined on each $10-\mathrm{cm}$ soil increment (Gardner 1965) on freshly collected samples. Percent moisture (weight) was determined at $1 / 3$ bar and 15 bars pressure. Air-dried samples from each $10-\mathrm{cm}$ increment of soil were analyzed for total Kjehldahl N (TKN) (Bremner 1965), organic matter (OM) (Allison 1965) sodium bicarbonate-soluble $\mathrm{P}\left(\mathrm{NaHCO}_{3}-\mathrm{P}\right)(\mathrm{Olsen}$ et al., 1954), texture (Day 1965), $\mathrm{pH}$, electrical conductivity (EC), and sodium adsorption ratio (SAR) from saturation extracts (Richards 1954). A T-test comparison of the green and brown areas was determined on all soil and plant parameters except for micronutrients.

\section{Results and Discussion}

\section{Soil Properties}

Composited soil physical and chemical characteristics with depth are shown in Table 1 for green and brown areas. The fact that these areas were within 3 meters of each other demonstrates the wide soil variability that exists (McGinnies et al. 1976). While the $0-10 \mathrm{~cm}$ layer classified as sandy loams for both areas, some brown areas had twice as much clay at the lower depths as did the green areas. In some instances as much as $40 \%$ clay was found in the brown areas. The green areas at this shallowest depth contained more silt. The textural difference at the $30-\mathrm{cm}$ depth probably greatly influenced plant growth characteristics because of its effect on water movement from above (precipitation), and from below (capillary movement from a shallow water table).

Nutrient availability indices (OM, TKN, $\left.\mathrm{NaHCO}_{3}-\mathrm{P}\right)$ were higher for the green areas. This relationship was not unexpected since the more favorable conditions in the green areas led to more top and root production, and consequently, more cycling and concentration of organic matter. Phosphorus was higher in the green areas for the surface soils. There was generally more mineral $\mathbf{P}$ at the lower depths in the brown areas. The slightly higher $\mathbf{P}$ values in the surface soil of the green areas probably resulted from 
Table 1. Physical and chemical soil characteristics of green and brown areas of Russian wildrye.

\begin{tabular}{|c|c|c|c|c|c|c|c|c|}
\hline \multirow[b]{2}{*}{ Parameters } & \multicolumn{8}{|c|}{ Depth (cm) } \\
\hline & $0-10$ & $10-20$ & $20-30$ & $30-40$ & $40-50$ & $50-60$ & $60-70$ & $70-80$ \\
\hline \multicolumn{9}{|l|}{ Green Area } \\
\hline Organic matter $(\%)$ & $4.22 *$ & $3.60^{*}$ & $1.65^{*}$ & $0.89 *$ & $0.72^{*}$ & 0.24 & 0.21 & 0.31 \\
\hline Total Kjehldahl nitrogen $(\%)$ & $0.23^{*}$ & $0.21^{*}$ & $0.10^{*}$ & $0.06^{*}$ & 0.03 & - & - & - \\
\hline $\mathrm{NaHCO}_{3}-\mathrm{P}(\mu \mathrm{g} / \mathrm{g})$ & $16^{*}$ & 14 & 9 & $7 *$ & 7 & 6 & 6 & 5 \\
\hline $\mathrm{pH}$ & 7.4 & $7.4^{*}$ & $7.4^{*}$ & $7.5^{*}$ & $8.0^{*}$ & $7.5^{*}$ & 8.3 & 8.4 \\
\hline Electrical conductivity $(\mathrm{dS} / \mathrm{m})$ & 0.88 & $0.91^{*}$ & $0.81 *$ & $1.00^{*}$ & $2.38 *$ & $0.91^{*}$ & $0.97^{*}$ & 1.10 \\
\hline Sodium adsorption ratio & 0.29 & $1.81^{*}$ & $0.71^{*}$ & $1.29^{*}$ & $3.15^{*}$ & $3.36^{*}$ & $4.54^{*}$ & 4.36 \\
\hline Sand $(\%)$ & 55 & 60 & 52 & 49 & 69 & $86^{*}$ & 88* & 88 \\
\hline Silt $(\%)$ & 35 & 28 & 34 & $35^{*}$ & $21^{*}$ & $5^{*}$ & $5^{*}$ & 4 \\
\hline Clay $(\%)$ & 10 & 12 & $14^{*}$ & $16^{*}$ & $10^{*}$ & $9 *$ & $7^{*}$ & 8 \\
\hline \multicolumn{9}{|l|}{ Brown Area } \\
\hline Organic matter $(\%)$ & 1.68 & 0.76 & 0.45 & 0.35 & 0.28 & 0.31 & - & - \\
\hline Total Kjehidahl nitrogen $(\%)$ & 0.11 & 0.11 & 0.05 & 0.01 & 0.01 & - & - & - \\
\hline $\mathrm{NaHCO}_{3}-\mathrm{P}(\mu \mathrm{g} / \mathrm{g})$ & 12 & 12 & 16 & 20 & 10 & 11 & 10 & - \\
\hline $\mathrm{pH}$ & 7.4 & 8.4 & 8.9 & 9.2 & 9.2 & 9.1 & 8.8 & - \\
\hline Electrical conductivity $(\mathrm{dS} / \mathrm{m}$ ) & 0.96 & 4.73 & 14.9 & 23.9 & 20.0 & 28.9 & 32.5 & - \\
\hline Sodium adsorption ratio & 5.00 & 20.8 & 60.5 & 27.8 & 68.8 & 40.8 & 32.0 & - \\
\hline Sand $(\%)$ & 59 & 63 & 62 & 59 & 62 & 61 & 56 & - \\
\hline Silt $(\%)$ & 29 & 27 & 8 & 11 & 12 & 15 & 22 & - \\
\hline Clay $(\%)$ & 12 & 10 & 30 & 30 & 26 & 24 & 22 & - \\
\hline
\end{tabular}

*Denotes significant differences at the $5 \%$ level between green and brown means for the same depth.

greater organic matter $\mathbf{P}$ mineralization while the lower values below resulted from greater use of mineral $P$ (more growth).

Salinity, sodicity indices in the brown areas indicated severe $\mathrm{Na}$ and salt problems. In the undisturbed areas the high $\mathrm{Na}$ at the $10-20 \mathrm{~cm}$ depth coupled with the transport of clay from above have created a natric horizon. This region (primarily B2nt) is extremely hard and impermeable to water from the top $A$ horizon and from the bottom $C$ horizon. In the plowed area sealing had quickly occurred in the top few centimeters in the brown areas because of the inversion of $\mathrm{C}$ horizon (high $\mathrm{Na}$ ) materials (Mueller 1983). Thus the condition for water intake had deteriorated from that provided initially by the natural soil (Robinson and Franklin 1971). Because of the dispersed nature of the soil and the sealing created by the downward movement of clay, rainfall precipitation in excess of $\mathbf{A}$ horizon field capacity resulted in standing water and subsequent evaporation and lateral run-off to natural drainages. Because the soil water in the $\mathrm{C}$ horizon under the brown areas could not be readily replaced by downward percolation, and because capillary movement upward was slow, the soil moisture in the profile was below wilting point to a depth of $50 \mathrm{~cm}$ in the brown areas (Fig. 1). In the green area, soil moisture was in the "available" range (between 15 and $1 / 3$ bar suction) below $20 \mathrm{~cm}$; this soil moisture kept the plants growing in the green area. Roots of the green plants extended to at least a depth of $60 \mathrm{~cm}$ to make use of this available water. In the brown areas, the high salt content in the soil below $20 \mathrm{~cm}$ had the combined effect of creating an estimated osmotic potential of 30 bars (estimated from EC) that further restricted water absorption by the plants.

As shown in Mueller's thesis work (1983) the problem of sealing resulted from plowing bringing the $\mathrm{C}$ horizon to the surface. Soil reaction at the $\mathrm{C}$ Horizon $(\mathrm{pH}>9.0)$ indicated high

Table 2. Dry matter (DM) yleld and chemical composition of Russian wildrye roots and tops associated with green and brown plants.

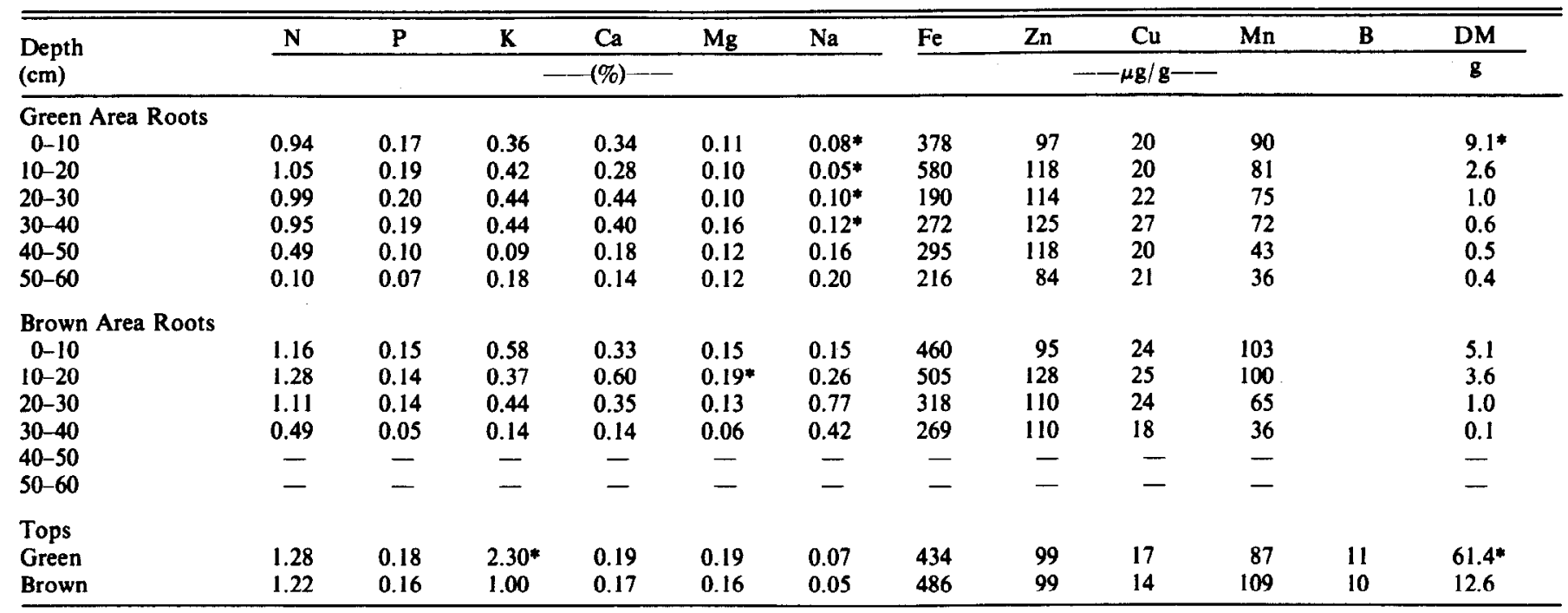

"Denotes significant differences at the $5 \%$ level between green and brown means for the same depth. 


\section{SOIL WATER (\%)}

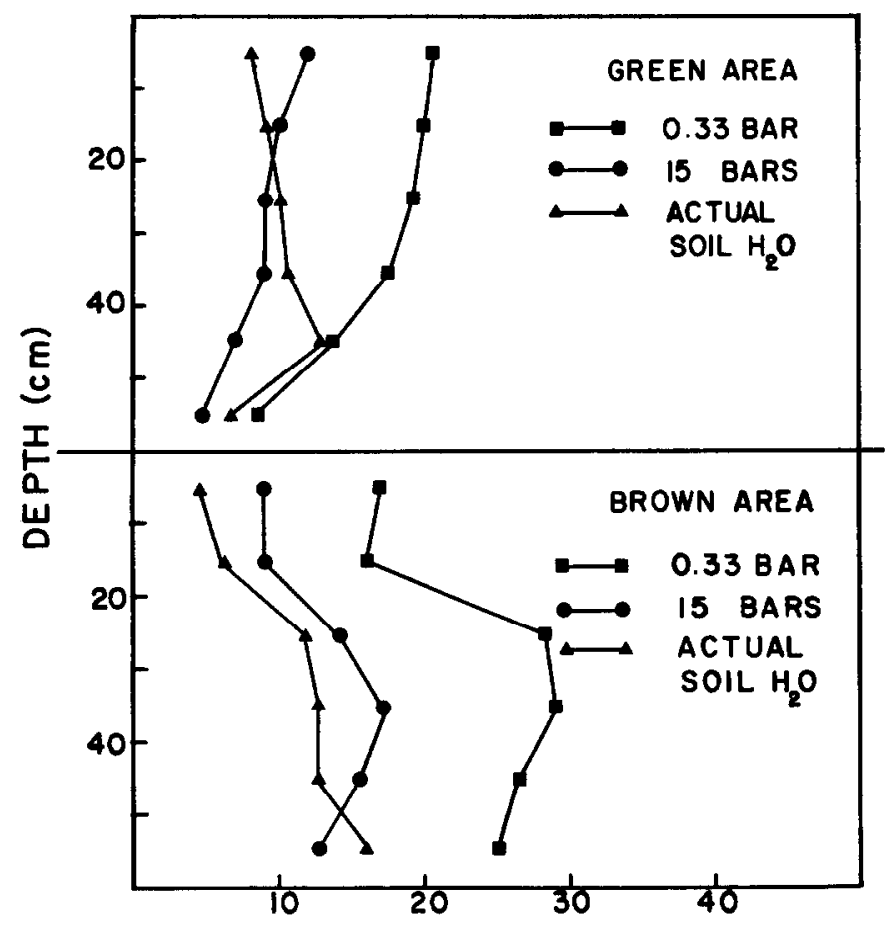

Fig. 1. Soil water relationships with depth in green and brown areas.

concentrations of carbonates and bicarbonates with the typical salt being primarily sodium sulfate $\left(\mathrm{Na}_{2} \mathrm{SO}_{4}\right)$, sodium chloride $(\mathrm{NaCl})$, and sodium bicarbonate-carbonate $\left(\mathrm{NaHCO}_{c}-\mathrm{Na}_{2} \mathrm{CO}_{c}\right)(\mathrm{McGin}-$ nies and Ludwig 1978). This predominance of $\mathrm{Na}_{2} \mathrm{CO}_{3}$ over $\mathrm{CaCO}_{3}$ ( $\mathrm{pH}>9.5$ in many instances) makes deep-plowing a questionable practice since the resultant seedbed is more apt to seal, crust, puddle, and provide greater osmotic stress (Toogood and Cairns 1978).

\section{Plant Properties}

The Russian wildrye plant data for both areas are given in Table 2. The most striking difference in areas was reflected by the fivefold increase in dry matter production in the green area over the brown area. Nutrient content in the tops at both areas did not suggest any major differences except maybe with respect to potassium (K), which could have been physically leached in the brown plants (Tukey 1970), and to manganese (Mn), which probably was still within acceptable limits of sufficiency (Epstein 1972). Specific toxic ions such as $\mathrm{Na}$ and $\mathrm{B}$ did not accumulate in large quantities in tops of the senescing Russian wildrye. Low sodium values in tops could be partially attributed to leaching and to specific uptake characteristics of Russian wildrye which appeared to possess an exclusion mechanism for Na (Bowman and McGinnies, 1981).

Root data showed green area root penetration of $60 \mathrm{~cm}$ while penetration in the brown area was only about one-half of that. Differences in root biomass, however, were not as dramatic as those found in the tops $(14.2 \mathrm{~g}$ versus $9.8 \mathrm{~g})$. Since the soil coring device was $15 \mathrm{~cm}$ in diameter, roots outside of this area were not included in our sampling. Thus, some roots were not accounted for and this loss would possibly be greater for the green area than for the brown (more superficial lateral roots).

Root chemical composition in the 2 areas primarily showed uptake differences with respect to $\mathrm{Na}$. Brown area roots exhibited nearly $0.8 \% \mathrm{Na}$ at the $30-40 \mathrm{~cm}$ depth, but this amount became less at the surface horizons. Green area roots had substantially less $\mathrm{Na}$ uptake. The K-Ca data suggested much greater resistance for $\mathrm{Ca}$ movement to the tops than for $\mathbf{K}$, but this phenomenon occurred in both areas. While the $36 \mu \mathrm{g} \mathrm{Mn} / \mathrm{g}$ appeared low, greater uptake at the surface soils resulted in adequate amounts of $\mathrm{Mn}$ in the plant tops. High fe values suggested some soil contamination.

\section{Soll-plant interactions}

Saline-sodic soils show unique relationships with respect to horizon stratifications and to $\mathrm{Na}$ and $\mathrm{Ca}$ relationships (Richards, 1954). This $\mathrm{Na}$ to $\mathrm{Ca}$ relationship was also expressed in the Russian wildrye plants (Fig. 2). At the $40-\mathrm{cm}$ depth, roots in the brown

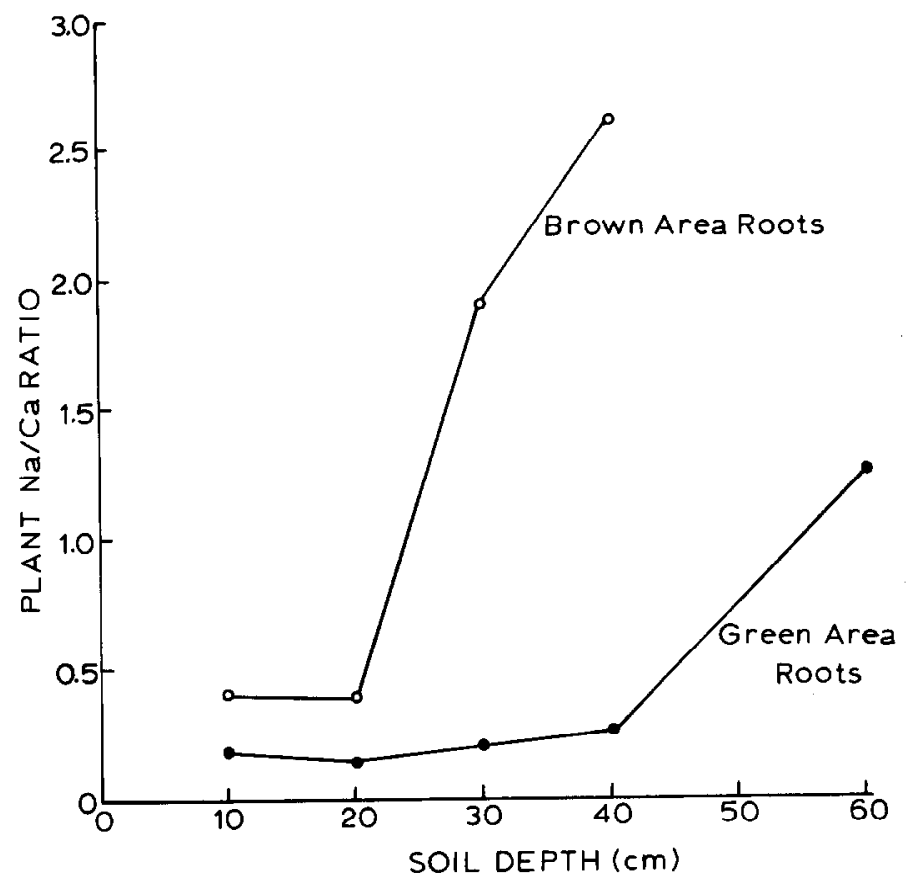

Fig. 2. $\mathrm{Na} / \mathrm{Ca}$ ratios of Russian wildrye roots as a function of depth in green and brown areas.

areas showed a 10 -fold increase in the $\mathrm{Na} / \mathrm{Ca}$ ratio over the green area roots. However, this relationship did not appear to affect the plant tops. This ratio narrowed at the lower depths since both SAR and EC increased in the green areas.

Various plant nutrient ratios were correlated with soil SAR. Plant $\mathrm{Na} / \mathrm{Ca}$ ratio was not significant, but both $\mathrm{Na} / \mathrm{Ca}^{1 / 2}$, and $\mathrm{Na} /[\mathrm{Ca}+\mathrm{Mg}) / 2]^{1 / 2}$ ratios were significant with SAR. Using plant $\mathrm{K}$ values did not improve correlations with soil SAR.

\section{Conclusions}

Russian wildrye did not show any excessive nutrient concentrations associated with salinity, sodicity, or boron. The roots did show some high $\mathrm{Na}$ concentrations in the brown areas. While salinity and sodicity contributed to the early browning noted in the field, it appeared that the main mechanisms affecting these changes were related to moisture availability. It can be postulated that in the brown areas, moisture was quickly lost to evapotranspiration because of the shallow or sparse nature of $A$ horizon material and the impervious nature of the sealed lower horizon. This condition probably led to shallow and sparse rooting which in turn resulted in quick desiccation under relatively short dry spells (1-2 weeks without added precipitation). Field observations indicate that the movement of water in the unrestricted zones of the green areas (presence of greater water storage capacity) resulted in completion of the life-cycle and production of seed heads in Russian wildrye. Restricted water movement in the brown areas resulted in failure or significant delay of plants to complete their life-cycle and produce seed heads as was also noted by Dodd and Coupland (1966). 
Although field testing to alleviate this problem is still in progress, it would appear that any cultural practice that improves or maintains water storage capacity (mulching, manuring, minimal disturbance of $\mathrm{C}$ horizon material) would help to solve this problem.

\section{Literature Cited}

Allison, L.E. 1965. Organic carbon. p. 1367-1379. In: C.A. Black, Editorin-chief. Methods of soil analysis, Part II. Amer. Soc. Agron. Madison, Wisc.

Bowman, R.A., and W.J. McGinnies. 1981. Tall wheatgrass and Russian wildrye growth on Natrustoll horizons treated with phosphate and calcium amendments. Agron. J. 73:933-936.

Bremner, J.M. 1965. Total nitrogen. p. 1149-1177. In: C.A. Black, Editorin-chief. Methods of soil analysis, Part II. Amer. Soc. Agron. Madison, Wisc.

Day, P.R. 1965. Particle fractionation and particle size analysis. p. 545-567. In: C.A. Black, Editor-in-chief. Methods of soil analysis, Part 1. Amer. Soc. Agron. Madison, Wisc.

Dodd, J.D., and R.T. Coupland. 1966. Vegetation of saline areas in Saskatchewan. Ecology 47:958-967.

Epstein, E. 1972. Mineral nutrition of plants: Principles and perspectives. John Wiley and Sons, Inc., New York.

Gardner, W.H. 1965. Water control. p. 82-127. In: C.A. Black, Editor-inchief. Methods of soil analysis, Part I. Amer. Soc. Agron. Madison, Wisc.
McGinnies, W.J., and J.R. Ludwig. 1978. Effects of Natrustoll soil horizons on germination, emergence, and growth of four grasses. Agron. J. 70: 1086-1088.

McGinnies, W.J.,R.W. Osborn, and W.H. Berg. 1976. Plant-soil-microsite relationships on a saltgrass meadow. J. Range Manage. 29:395-400.

Mueller, D.M. 1983. Establishment of Russian wildrye on a saltgrass meadow. M.S. Thesis. Range Sci. Dep. Colorado State Univ., Fort Collins, Colo.

Olsen, S.R., C.V. Cole, F.S. Watanabe, and L.A. Dean. 1954. Estimation of available phosphorus in soils by extraction with sodium bicarbonate. USDA Cir. 939.

Richards, L.A. 1954. Diagnosis and improvement of saline and alkali soils. USDA Handbook, No. 60.

Robinson, C.W., and W.T. Franklin. 1971. Effect of simulated deep plowing on reclamation of a saline-sodic soil. Colorado State Univ. Exp. Sta. Progr. Rep. No. 71-22.

Soltanpour, P.N., and S.M. Workman. 1981. Soil testing methods used at Colorado State University soil testing laboratory for the evaluation of fertility, salinity, sodicity, and trace element toxicity. Tech. Bull. 142. Fort Collins, Colo.

Toogood, J.A., and R.R. Cairns. 1978. Solonetzic soils technology and management. Bulletin B-78-1 2nd edition. Univ. Alberta, Edmonton, Alberta, Canada.

Tukey, H.B., Jr. 1970. The leaching of substances from plant. Ann. Rev. Plant Physiol. 21:305-332.

\section{RANGELAND HYDROLOGY}

by Farrel A. Branson, Gerald F. Gifford, Kenneth G. Renard, and Richard F. Hadley

Unique in its emphasis on the hydrology of rangelands, primarily arid and semiarid lands. RANGELAND HYDROLOGY provides a text for one aspect of range management where none has existed before. This expanded Second Edition presents in-depth information for those who must manage rangeland or respond to questions about the impacts of land use practices on hydrology.

Included in the new Second Edition are a chapter on modeling with approaches to predicting the effects of land use, and a chapter on the rapidly developing field of snow pack management.

The 352-pages include 197 illustrations, providing rapid access to an assembly of data found nowhere else and useful in the preparation of environmental impact statements. Extensive bibliographic material with each chapter and a subject matter index add to the useableness of the book.

Range scientists and managers, soil conservationists, hydrologists, agricultural engineers, land reclamation specialists, wildlife managers, graduate and undergraduate students and their professors, as well as all interested in the hydrology of arid lands will find RANGELAND HYDROLOGY a valuable addition to their libraries. (352 pages paper laminated cover $\$ 15.00$ US) 